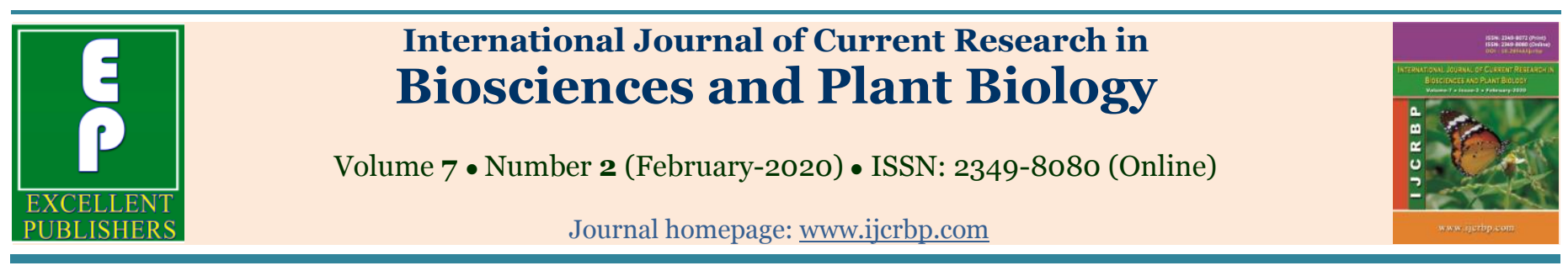

\title{
Evaluation of the quality of a yogurt produced by partial substitution of cow milk by soybean milk in Benin
}

\author{
René G. Degnon ${ }^{1 *}$, Christian T. R. Konfo',2, Brice Kpatinvoh"1, \\ Hermine C. Bossa ${ }^{1}$ and Y. Nelly Dagnon ${ }^{1}$
}

\begin{abstract}
${ }^{1}$ University of Abomey-Calavi, Polytechnic School of Abomey-Calavi, Laboratory of Study and Research in Applied Chemistry, 01 PO Box: 2009 Cotonou, Benin

${ }^{2}$ National University of Agriculture (UNA), Schools of Science and Techniques for Preservation and Processing of Agricultural Products (ESTCTPA), Food and Bioresources and Human Nutrition Science and Technology Laboratory,
\end{abstract} PO Box 114, Ayita (Sakété), Benin

*Corresponding author; e-mail: gnimabou2002@yahoo.fr

\begin{tabular}{|c|c|}
\hline Article Info & \multirow{4}{*}{$\begin{array}{l}\text { Yogurt is a food with recognized nutritional qualities. It is both rich in many nutrients } \\
\text { (proteins, calcium, vitamins). It is produced by fermentation of cow's milk by specific } \\
\text { bacteria (Lactobacillus bulgaricus and Streptococcus thermophilus). Unfortunately, } \\
\text { the economic situation in developing countries has made the supply of milk powder for } \\
\text { yoghurt production very difficult and unprofitable. The aim of this study is to partially } \\
\text { substitute powdered milk with soy milk for yoghurt production. It consisted in the } \\
\text { fermentation of cow's milk combined with } 25,50 \text { and } 75 \% \text { of the soya milk. The } \\
\text { microbiological and organoleptic characteristics of samples allowed identifying the } \\
\text { most appreciated by the tasters. The latter have undergone a nutritional analysis. } \\
\text { Results revealed that the products have good microbiological quality. Nevertheless } \\
\text { regarding the alleged coliforms the results obtained are not in agreement with the } \\
\text { standard. Sensory analyzes revealed that the best formulation was that containing } 25 \% \\
\text { soy milk. Nutritional analyzes have revealed that these samples have variable } \\
\text { characteristics compared to the control yogurt (cow's milk based) with regard to the dry } \\
\text { matter (14.18\% against } 22.75 \%) \text { the titratable acidity ( } 2.22 \mathrm{~g} / \text { against o3 } \mathrm{g} / \mathrm{l} \text { ), the pH } \\
\text { (3.1 against } 3.1 \text { ), and are richer in proteins ( } 16.25 \% \text { against } 13.125 \%) \text {. It was concluded } \\
\text { therefore that the yoghurt of very good quality could be produced by incorporation of } \\
25 \% \text { of soya milk. }\end{array}$} \\
\hline $\begin{array}{l}\text { Date of Acceptance: } \\
12 \text { January } 2020\end{array}$ & \\
\hline Keywords & \\
\hline $\begin{array}{l}\text { Ferments } \\
\text { Lactic bacteria } \\
\text { Milk powder } \\
\text { Soy milk } \\
\text { Yogurt }\end{array}$ & \\
\hline
\end{tabular}

\section{Introduction}

Milk is an excellent source of nutrients such as vitamins, amino acids, fats, minerals, proteins and sugars, thus forming an excellent microbial growth medium (Hajirostamloo, 2009). In developing countries and especially in the tropical regions of
sub-Saharan Africa (except East Africa), production of milk and milk products is limited and expensive (Fashakin and Unokiwedi, 1992). Yoghurt is part of the family of fermented milks obtained by the development of the specific thermophilic lactic bacteria Streptococcus thermophilus and Lactobacillus bulgaricus which 
must be sown simultaneously and be alive in the product at a rate of at least 10 million bacteria per gram of products (Tamime, 2002). Yoghurt has excellent digestibility compared to milk, even in people who are intolerant to milk lactose, because yoghurt contains less lactose and has a beneficial effect on the intestinal flora (Heyman, 2006). However, nowadays many less advanced countries suffer from a lack of fresh milk which is largely due, according to some authors, to climatic conditions, farming practices and diseases caused by parasites (Fashakin and Unokiwedi, 1992). This shortage has affected, to a large extent, the amount of protein used for feeding children and adults (Nicol et al. 2011). In a global context characterized by a food crisis resulting in a significant rise in the prices of basic necessities, the supply of milk powder for the production of yogurt has become very difficult and unprofitable. Faced with all these difficulties, it is necessary to explore other horizons to reach an acceptable solution. It is then necessary to look for other sources of milk that can validly replace cow's milk. Moreover, cheaper plant-based milk can be extracted from soybeans and other legumes and used as a substitute for cow's milk (Bridges, 2018). In addition, the consumption of soy and its derivatives has beneficial effects on health (Sánchez-Calvoet al., 2013).

Therefore, the combination of reconstituted milk powder and soy milk in very good hygienic conditions can make yogurt, a good quality product (Ghoneem et al., 2018). The development of such yogurts is justified by an evolving and particularly demanding competitive business environment where research and development of new products and the quality approach are drivers of business expansion. Thus, the present study forming part of this logic proposes to partially replace milk powder with soy milk for the production of yoghurt. The objective of this study is to partially substitute milk powder with soy milk in the production of yoghurt.

\section{Materials and methods}

\section{Raw materials}

The main raw materials involved in this production are milk powder, ferment and soy milk, sugar, water, milk powder, and vanilla aroma were purchased at the store in Ouando (Porto-Novo). Soymilk was produced in the Songhai Center Dairy
Section. Yogurt-specific lactic ferments (Lactobacillus bulgaricus and Streptococcus thermophilus) were purchased at the pharmacy at Porto-Novo.

\section{Experimental plan}

Soymilk has been incorporated in different proportions (25\%, 50\% and 75\%). Two categories of witnesses were taken into account. These are yoghurt samples produced with milk powder and those produced with soy milk).

\section{Manufacturing processes of yoghurt}

The yogurt was produced after blending various proportions of extracted soy milk and milk powder after the heat treatments. Thus, the soy milk and the milk powder are respectively preheated to $100^{\circ} \mathrm{C}$ for $5 \mathrm{~min}$ and pasteurized at $80^{\circ} \mathrm{C}$ for 15 seconds after adding the sugar before being cooled to $45-50^{\circ} \mathrm{C}$ for the first time, mix to prevent the sugar from sitting at the bottom of the milk. Then add the quantity of milk powder and whisk the mixture to avoid lumps. Return the mixture to the heat and let it heat to a temperature of $80-85^{\circ} \mathrm{C}$ (pasteurization). The objective of this operation is to reduce the microbial load of the dairy solution, and cooled to a temperature of $50^{\circ} \mathrm{C}$ to $45^{\circ} \mathrm{C}$. The ferment (Lactobacillus bulgaricus and Streptococcus thermophilus), and the aroma was added to the cooled solution (seeding). The seeded solution is then homogenized by whipping and filtered. The filtration is done using a fine mesh filter and aims the elimination / separation of all impurities and anybody whose size is greater than the mesh of the filter. It was added to this mixture $2 \mathrm{ml}$ of aroma (vanilla). After filtration, the mixture obtained is then packaged in the pots. These pots are then put in the incubator at a temperature of $45^{\circ} \mathrm{C}$ for $3-4$ hours maximum time for fermentation and yoghurt formation. After the yogurt has been formed, the jars are then removed from the incubator and put in the fridge at $+4^{\circ} \mathrm{C}$ to slow down the fermentation process and guarantee a shelf life.

\section{Microbiological analysis}

Samples microbiological parameters were evaluated by using standard methods. Thus, the total mesophilic aerobic flora was enumerated by 
inoculation on the Plate Count Agar medium (PCA) and incubation at $30^{\circ} \mathrm{C}$ for $24-48 \mathrm{~h}$ (NF Vo8-051), whereas the total and thermotolerant coliforms were searched on the Violet Red Bile Lactose medium (VRBL) with incubation at 30 and $44^{\circ} \mathrm{C}$ respectively for $24 \mathrm{~h}$ (NF Vo8-050). Positive coagulase Staphylococci was tested on Baird Parker medium with incubation at $37^{\circ} \mathrm{C}$ for $24-48$ (NF EN ISO 6888-1 / A1), while yeasts and molds on Sabouraud medium with chloramphenicol were incubated at $25^{\circ} \mathrm{C}$ for 3 to 5 days (NF Vo8-059). The anaerobic sulpho-reducing bacteria were investigated on Tryptone Sulfite Neomycin (TSN) agar with incubation at $46^{\circ} \mathrm{C}$ for $20 \mathrm{~h}$ (NF ISO 15213). Finally Salmonella search was performed by pre-enrichment of the stock solution at $37^{\circ} \mathrm{C}$ for $19 \mathrm{~h}$. Enrichment was made on Rappaport Vassiliadis (RV), Müller Kaüffmann (KM) media and isolation on Xylose-Lysine-Decarboxylate (XLD) and Hektoen media (ISO 6579).

\section{Sensory analysis}

The sensory characters of the different samples were evaluated by 30 judges familiar with yoghurt. The evaluated characters were: color, taste, aroma, smell, texture and overall acceptability, on a scale of 1 to 7 (from very unpleasant to very pleasant).

\section{Physicochemical/nutritional analysis}

The $\mathrm{pH}$ was measured with a digital $\mathrm{pH}$-meter (HANNA HI 98129). Acidity of samples, expressed as citric acid content per unit of volume, was determined by titration with 0.01 $\mathrm{mol} / \mathrm{L}$ of sodium hydroxide solution, using phenolphthalein as indicator. Dry matter and moisture content were determined according to AOAC (1984) method while protein was analyzed by the Microkjedhal nitrogen method, using a conversion factor of 6.25 .

\section{Statistical analysis}

Data from three independent replicate trial were subjected to statistical analysis using Minitab 16. Differences between means were compared with ANOVA testat the significance level of $5 \%$. Sensory analysis has been the subject of a Principal Component Analysis (PCA) in this same software.

\section{Results}

\section{Microbiological characteristics of the samples}

The microbiological analyzes results were recorded in the Table 1. Analysis of this table revealed a complete absence of pathogenic germs such as sulpho-reducing bacteria and salmonella in both samples. There are also fewer than 10 germs such as thermotolerant coliforms, $E$. coli and coagulase positive staphylococci.

The number of total coliforms is in the order of 1.3 $\times 10^{2} \mathrm{CFU} / \mathrm{g}$ in soy milk yoghurt and less than 10 in the control yoghurt. Total bacteria were counted in all the samples between $3.1 \times 10^{3}$ (yoghurt with soy milk) and $3.4 \times 10^{4} \mathrm{CFU} / \mathrm{g}$ (yogurt with $50 \%$ soy milk). The lactic flora had better multiplied in the yoghurt with cow's milk $\left(5.8 \times 10^{7} \mathrm{CFU} / \mathrm{g}\right)$ and in yogurt with $25 \%$ soy milk $\left(5.28 \times 10^{7} \mathrm{CFU} / \mathrm{g}\right)$.

Table 1. Microbiological characteristics of samples.

\begin{tabular}{|c|c|c|c|c|c|c|}
\hline \multirow[b]{2}{*}{ Microorganisms } & \multicolumn{2}{|c|}{ Control: Yogurt with } & \multicolumn{3}{|c|}{ Yogurt with } & \multirow{2}{*}{$\begin{array}{l}\text { Microbiological } \\
\text { criteria }\end{array}$} \\
\hline & Cow's milk & Soymilk & $\begin{array}{l}25 \% \\
\text { Soymilk }\end{array}$ & $\begin{array}{l}50 \% \\
\text { Soymilk }\end{array}$ & $\begin{array}{l}75 \% \\
\text { Soymilk }\end{array}$ & \\
\hline TB (CFU/g) & $10^{4}$ & $3.1 \times 10^{3}$ & $1.2 \times 10^{4}$ & $3.4 \times 10^{4}$ & $3.2 \times 10^{4}$ & $5.0 \times 10^{4}$ \\
\hline $\mathrm{TC}(\mathrm{CFU} / \mathrm{g})$ & $<10$ & $<10$ & $<10$ & $<10$ & $<10$ & $1.0 \times 10^{2}$ \\
\hline Th C (CFU/g) & $<10$ & $<10$ & $<10$ & $<10$ & $<10$ & $<10$ \\
\hline \multirow[t]{2}{*}{$\mathrm{YM}(\mathrm{CFU} / \mathrm{g})$} & $\mathrm{Y}:<10$ & $\mathrm{Y}:<10$ & $\mathrm{Y}:<10$ & $\mathrm{Y}:<10$ & $\mathrm{Y}:<10$ & - \\
\hline & $\mathrm{M}:<10$ & $\mathrm{M}:<10$ & $\mathrm{M}:<10$ & $\mathrm{M}:<10$ & $\mathrm{M}:<10$ & - \\
\hline $\mathrm{Sal}(\mathrm{CFU} / \mathrm{g})$ & Absent & Absent & Absent & Absent & Absent & - \\
\hline
\end{tabular}

TB : Total bacteria ; LAB : lactic acid bacteria; SRB: Sulfito- reducing bacteria; YM: Yeasts and Mold;

Sal: Salmonella; TC: total coliforms; Th C thermotolerant coliforms; Staph: Positive coagulase Staphylococci 


\section{Organoleptic characteristics of yogurts}

The analysis in Fig. 1 reveals that, according to the tasters, the samples that received $25 \%$ soymilk were appreciated for all the parameters evaluated (texture, taste, aroma, color and overall appreciation). This range of samples was therefore had the organoleptic characteristics close to those of the control yogurt, cow's milk product only. On this basis, only the yoghurt produced by substitution of $25 \%$ of cow's milk by the soybean milk that has been characterized physico-chemically and on nutritional plan.
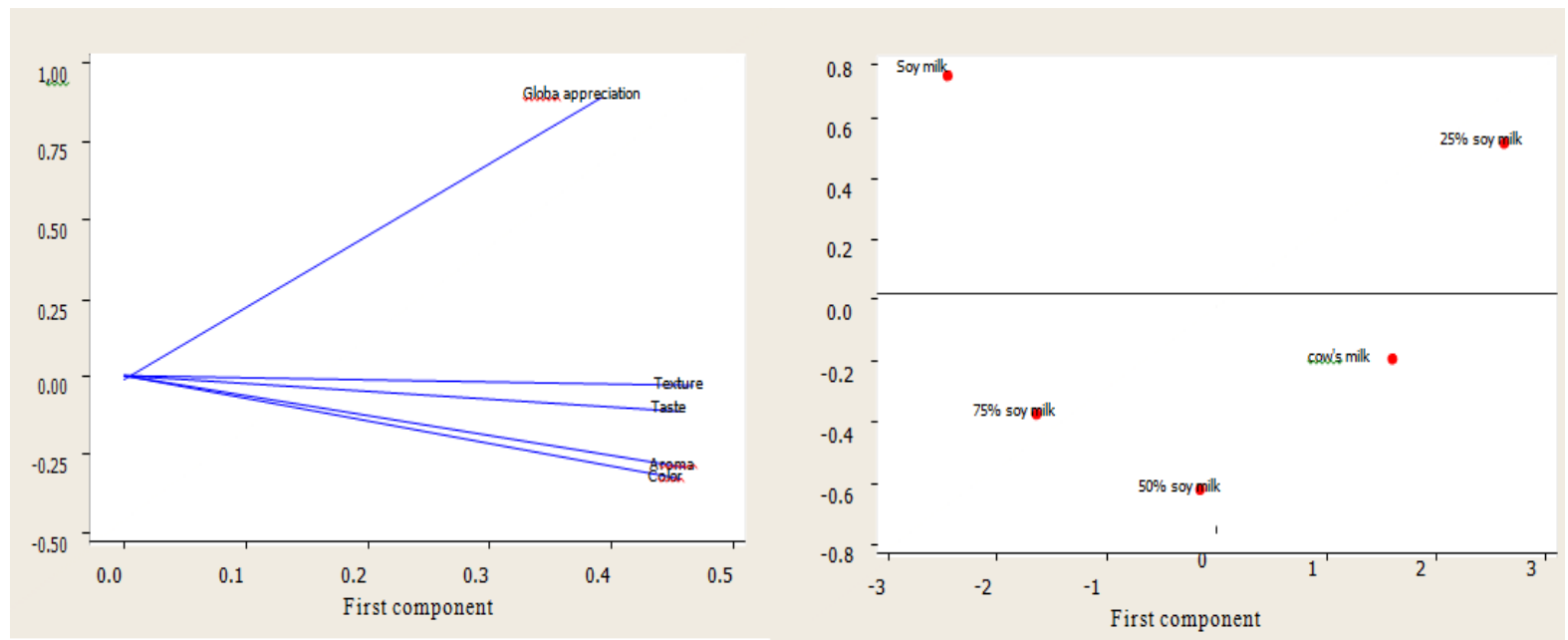

Fig. 1. Organoleptic characteristics of sample.

\section{Physicochemical and nutritional characteristics of yogurt retained}

The nitrogen and protein contents of soy milk yogurt are higher than those of the control yoghurt $(2.6 \pm 0.14$ against $2.4 \pm 0.42$ and $16.25 \pm 0.88$ against $15.00 \pm 2.62$ ) respectively (Table 2). In addition, the water content of soy milk yoghurt $(85.82 \pm 1.72)$ is also higher than that of the control yogurt $(77.255 \pm 0.233)$. In contrast, the dry matter content of soy milk yoghurt $(14.185 \pm$ 1.725) is lower than that of the control yoghurt $(77.255 \pm 0.233)$. The same observation was made with respect to the titratable acidity content of soy milk yogurt $(2.2250 \pm 0.5303)$ lower than that of the control yoghurt $(3.000 \pm 0.141)$. Finally, the $\mathrm{pH}$ of soy milk yogurt $(3.117 \pm 0.003)$ is slightly higher than that of the control yoghurt.

Table 2. Physico-chemical profile of yogurt developed compared to controls.

\begin{tabular}{lll}
\hline Parameters & Yogurt with 25\% soymilk & Control yogurt \\
\hline Nitrogen content (\%) & $2.600 \pm 0.141 \mathrm{a}$ & $2.400 \pm 0.424 \mathrm{a}$ \\
Protein content (\%) & $16.250 \pm 0.884 \mathrm{a}$ & $15.000 \pm 2.652 \mathrm{a}$ \\
Dry matter content (\%) & $14.185 \pm 1.725 \mathrm{~b}$ & $22.745 \pm 0.233 \mathrm{a}$ \\
Water content (\%) & $85.815 \pm 1.725 \mathrm{a}$ & $77.255 \pm 0.233 \mathrm{~b}$ \\
Titratable acidity & $2.225 \pm 0.530 \mathrm{a}$ & $3.000 \pm 0.141 \mathrm{a}$ \\
pH & $3.117 \pm 0.004 \mathrm{a}$ & $3.100 \pm 0.000 \mathrm{a}$ \\
\hline
\end{tabular}

On the same line, the values carrying the same letters are not significantly different at $5 \%$.

\section{Discussion}

Yogurt is part of the family of fermented milks obtained by the development of two lactic acid bacteria Streptococcus thermophilus and
Lactobacillus bulgaricus, which must be seeded simultaneously and be found alive in the product at the rate of at least 10 million bacteria per gram of products (Assam and Idiri, 2015). In developing countries like Benin, household access to cow's 
milk is still a luxury. In this country, in addition to the insufficient milk production observed, some people tolerate it poorly by developing allergies, hence the interest in soy milk (Bokossa et al., 2011). This milk is similar in appearance to cow's milk and of interesting nutritional value; it is often used as a substitute for cow's milk in food and cooking, in particular vegetarian and especially vegan (Rinaldoni et al., 2012; Ghoneem et al., 2018).

The results obtained from the analyses showed that the water content $(91.18 \%)$ of the soy milk is slightly lower than (94.18 $\pm 0.042 \%)$, obtained by Bokossa et al. (2011). This difference could be due to the water content of the seeds used. Similarly, the high protein content (46.63\%) of yogurt incorporated in soy milk compared to milk powder $(31.5 \%)$ is due to the fact that soybean is a potential source of protein with $44.6 \%$ and $45 \%$ (Martin et al. 2010). Although differences in the $\mathrm{pH}$, dry matter, and titratable acidity of yogurts are not significant, yoghurt at $25 \%$ in soy milk appears to be more acidic than standard yoghurt (100\% milk in powder). This could be explained on the one hand by the fact that the soymilk used for the production of yogurts is slightly acidic than milk powder. On the other hand, it could be said that soymilk contains substances which, once in contact with the elements of the milk powder, increase the fermentative power of the lactic acid bacteria and consequently acidify the medium. This acidification could be a major advantage from a hygienic point of view, since it could prevent the growth of most pathogenic germs and thus ensure the conservation of yoghurt (Konfo et al., 2014). The high protein content of yogurt with $25 \%$ of soy milk is linked to the fact that it received more soy milk which would be high-protein milk (46.63\%).

From microbiological analyzes, it can be concluded that the product could have a satisfactory quality if presence of suspected coliforms had not been counted. It is also necessary to respect the rules of hygiene for a product of better quality. In addition, sensory analysis results show that yogurt with $25 \%$ soy milk has sensory characteristics similar to that of $100 \%$ powdered yoghurt, which would be linked to the method of extraction of soymilk and the heat treatment that this milk undergoes before use. Thus the milling method reported by AWORH (1987) would have improved the organoleptic characteristics of soy milk and consequently yogurt. This improvement would be due to a reduction of the odor caused by lipoxygenases, which would have allowed the tasters to find that yogurts have the same smells and the same tastes and to make their choices on the $25 \%$ one with soy milk.

\section{Conclusion}

The results obtained from the sensory study show that powdered milk can be substituted by $25 \%$ of soy milk in order to produce yogurt without compromising the acceptability of the final product. Thus the yogurt with high protein content produced and whose production technology is developed, can not only improve the socioeconomic life of producers, but also can meet the protein needs of consumers. To this end, parameters such as microbiological characteristics were studied, and reveal that the soy milk yogurt had satisfactory quality. The physico-chemical characteristics studied show that soy milk yogurt is richer in protein $(16.25 \%)$, in water $(85.82 \%)$, in nitrogen $(2.6 \%)$ compared to the control yogurt. Other processes must be tried later, always in the direction of improving yogurt based on the mixture of soy milk and milk powder in order to enhance its acceptability.

\section{Conflict of interest statement}

Authors declare that they have no conflict of interest.

\section{Acknowledgement}

The authors thank all the staff of the Songhai Center of Porto Novo in Benin whose contribution to the realization of this work is invaluable.

\section{References}

AOAC, 1984. Official Methods of Analysis. $18^{\text {th }}$ Edn., Arlington, Benin. 16p.

Assam, T., Idiri, F., 2015. Essai de fabrication de yaourts brassés aromatisés à base de lait de vache et lait de soja. Étude comparative des différents paramètres (Doctoral dissertation, Université Mouloud Mammeri).

Aworh, O. C., Muller, H. G., 1987. Cheese-making properties of vegetable rennet from Sodom 
apple (Calotropis procera). Food Chem. 26(1), 71-79.

Bokossa, Y., Tchekessil, P., Dossouy, M., Egounlety, R., 2011. Substitution partielle du lait en poudre par le lait de soja pour la production du yaourt. Bull. Rech. Agron. Bénin Numéro 69 - Juin 2011.

Bridges, M., 2018. Moo-ove Over, Cow's Milk: The Rise of Plant-Based Dairy Alternatives. Practical Gastroenterology, 21.

Fashakin, J. B., Unokiwedi, C. C., 1992. Chemical analysis of "warankasi" prepared from cow milk partially substituted with melon milk. Niger. Food J. 10, 103-109.

Ghoneem, G., Ismail, M., El-Boraey, N., Tabekha, M., Elashrey, H., 2018. Optimal combination of soy, buffalo, and cow's milk in bioyogurt for optimal chemical, nutritional, and health benefits. J. Amer. Coll. Nutr. 37(1), 8-16.

Hajirostamloo, B., 2009. Comparison of nutritional and chemical parameters of soymilk and cow milk.World Acad. Sci. Eng. Technol. 57(9), 436-438.

Heyman, M. B., 2006. Lactose intolerance in infants, children, and adolescents. Pediatrics. 118(3), 1279-1286.

ISO 6579-1, 2017. Microbiologie de la chaîne alimentaire. Méthode horizontale pour la recherche, le dénombrement et le sérotypage des Salmonella - Partie 1: Recherche des Salmonella spp.

Konfo, C. T., Chabi, N. W., Agbadjizo, J., Dahouenon-Ahoussi, E., Soumanou, M. M., Sohounhloue, D. C., 2014. Influence de la feuille de Hemizygia bracteosa (Benth) sur la qualité de la bière du sorgho" tchakpalo" produite au Bénin. Int. J. Innov. Appl. Stud. 7(2), 453-463.

Martin, H., Laswai, H., Kulwa, K., 2010. Nutrient content and acceptability of soybean based complementary food. Afr. J. Food Agric. Nutr. Develop. 10(1), 2040-2049.
NF ISO 15213，2003. Microbiologie des aliments Méthode horizontale pour le dénombrement des bactéries sulfito-réductrices se développant en conditions anaérobies.

NF Vo8-050, 1999. Food Microbiology. Coliform counts by counting the colonies obtained at $30^{\circ} \mathrm{C}$. Routine method.

NF Vo8-051, 1999. Food Microbiology. Enumeration of Microorganisms by Counting the Colonies Obtained at $30^{\circ} \mathrm{C}$. Routine method.

NF Vo8-052, 1997. Food Microbiology. Detection of Salmonella. Routine Method.

NF Vo8-059, 2002. Food Microbiology. Enumeration of Yeasts and Molds by Counting Colonies at $25^{\circ} \mathrm{C}$. Routine method.

Nicol, J. M., Turner, S. J., Coyne, D. L., Den Nijs, L., Hockland, S., Maafi, Z. T., 2011. Current nematode threats to world agriculture. In Genomics and molecular genetics of plantnematode interactions. Springer, Dordrecht. pp. 21-43.

Park, D. J., Oh, S., Ku, K. H., Mok, C., Kim, S. H., Imm, J. Y.. 2005. Characteristics of yogurt-like products prepared from the combination of skim milk and soymilk containing saccharifiedrice solution. Int. J. Food Sci. Nutr. 56(1), 2334 .

Rinaldoni, A. N., Campderrós, M. E., Padilla, A. P., 2012. Physico-chemical and sensory properties of yogurt from ultrafiltreted soy milk concentrate added with inulin. LWT-Food Sci. Technol. 45(2), 142-147.

Sánchez-Calvo, J. M., Rodríguez-Iglesias, M. A., Molinillo, J. M., Macías, F. A., 2013. Soy isoflavones and their relationship with microflora: beneficial effects on human health in equal producers. Phytochem. Rev. 12(4), 979-1000.

Tamime, A. Y., 2002. Fermented milks: a historical food with modern applications-a review. Eur. J. Clin. Nutr. 56(4), S2-S15.

\section{How to cite this article:}

Degnon, R. G., Konfo, C. T. R., Kpatinvoh, B., Bossa, H. C., Dagnon, Y. N., 2020. Evaluation of the quality of a yogurt produced by partial substitution of cow milk by soybean milk in Benin. Int. J. Curr. Res. Biosci. Plant Biol. 7(2), 1-6. doi: https://doi.org/10.20546/ijcrbp.2020.702.001 